\begin{tabular}{|c|c|c|c|c|}
\hline $\begin{array}{c}\text { Jurnal Penelitian \& } \\
\text { PPM }\end{array}$ & ISSN: 2442-448X & Vol 4, No: 2 & Hal: $129-389$ & Juli 2017 \\
\hline
\end{tabular}

\title{
KONDISI SOSIAL MASYARAKAT DI SEKITAR PERUSAHAAN DI DESA KERTAJAYA KECAMATAN PADALARANG KABUPATEN BANDUNG BARAT
}

\author{
OLEH: \\ RISNA RESNAWATYN \& MUHAMMAD FEDRYANSYAH \\ 1. Departemen Kesejahteraan Sosial FISIP Universitas Padjadjaran \\ 2. Departemen Kesejahteraan Sosial FISIP Universitas Padjadjaran \\ Email: \\ (risna.resnawaty@unpad.ac.id; muhammad.fedryansyah@unpad.ac.id)
}

\begin{abstract}
ABSTRAK
Pemahaman mengenai kondisi sosial masyarakat di sekitar perusahaan merupakan salah satu faktor yang penting dalam pelaksanaan program Corporate Social Responsibility. Pemahaman tersebut mencakup gambaran yang komprehensif mengenai masyarakat sehingga dapat menjadi landasan dalam perancangan program. Penelitian ini bertujuan untuk mendeskripsikan kondisi sosial masyarakat yang tinggal di wilayah industri khususnya di Desa Kertajaya Kecamatan Padalarang Kabupaten Bandung Barat. Metode yang digunakan dalam penelitian ini adalah kualitatif dengan melakukan analisis berdasarkan interpretasi dari data primer maupun sekunder. Adapun gambaran mengenai kondisi sosial masyarakat dapat dilihat dari kondisi sosial dan ekonomi masyarakat. Hasil dari penelitian ini adalah masyarakat masih memegang teguh nilai-nilai lokal meskipun jumlah penduduk pendatang semakin meningkat. Kemudian, kondisi ekonomi masyarakat dapat dilihat dari pergeseran mata pencaharian dari petani menjadi industri.
\end{abstract}

Kata kunci : pengembangan masyarakat, pemetaan sosial

\begin{abstract}
One of the factors affecting the implementation of CSR program is the understanding of the community environment by the company. This understanding includes a comprehensive picture of the community as the bases in program design. This study aims to describe the social conditions of community in industrial areas, especially in Desa Kertajaya Kecamatan Padalarang, Kabupaten Bandung Barat. The method used in this research is qualitative by doing analysis based on interpretation from primary and secondary data. The description of the social condition of the community can be seen from the social and economic conditions of the community. The result of this study is that the community still holds the local values even though the number of migrant population is increasing. Then, the economic condition of society can be seen from the shift of livelihood from farmers to industry.
\end{abstract}

Key words : community development, social mapping

\section{Pendahuluan}

Salah satu kegagalan kegiatan Corporate Social Responsibility (CSR) yang dilakukan oleh perusahaan di banyak tempat adalah kurangnya pertimbangan kebutuhan dari sudut pandang masyarakat. Banyak perusahaan yang melaksanakan CSR khusunya dalam bentuk pengembangan masyarakat didasarkan kepentingan perusahaan dan berdasarkan sudut pandang perusahaan. Akibatnya perusahaan 
kesulitan dalam memahami keadaan sosial suatu masyarakat. Hal ini mengakibatkan keterbatasan informasi yang dimiliki pelaksana program untuk merancang kegiatan yang sesuai dengan peta masalah dan potensi masyarakat. Oleh sebab itu perusahaan harus mempunyai peta sosial mengenai karakteristik, kebutuhan, dan potensi dari masyarakat yang akan diberikan program CSR. Kegiatan untuk mendapatkan informasi mengenai karakteristik, kebutuhan, dan potensi dari suatu masyarakat dapat dikatakan sebagai pemetaan sosial.

Pemetaan sosial adalah sebuah cara untuk memperoleh gambaran utuh mengenai kondisi sosial masyarakat. Pemetaan sosial adalah alat untuk mencari, mendeskripsikan, menganalisis, dan memprediksi kondisi sosial suatu masyarakat. Dengan adanya infrmasi hasil pemetaan sosial, perusahaan dapat memanfaatkan informasi dari hasil pemetaan sosial untuk merancang program CSR yang sesuai dengan kebutuhan dan tepat sasaran. Hal tersebut akan dapat mengurangi resiko kegagalan, dan pada akhirnya masyarakat selaku penerima program akan merasakan manfaat dari program CSR tersebut.

Keberhasilan pelaksanaan CSR tidak terlepas dengan kebermanfaatan dari program CSR itu sendiri. Kebermanfaatan CSR bagi masyarakat akan dirasakan jika program CSR sudah sesuai dengan kebutuhan dan potensi yang dimiliki oleh masyarakat itu sendiri. Oleh sebab itu dibutuhkan adanya pemetaan sosial terhadap kebutuhan dan potensi masyarakat, sehingga dalam memenuhi kebutuhan masyarakat disesuaikan dengan potensi yang dimiliki oleh masyarakat yang bersangkutan. Pemetaan sosial sebagai proses penggambaran masyarakat secara sistematis dan melibatkan pengumpulan data dan informasi mengenai masyarakat termasuk didalamnya profil dan masalah sosial yang ada pada masyarakat tersebut (Suharto : 1997). Pemetaan sosial ini menjadi penting karena akan berhubungan dengan ketepatan dari program CSR yang telah dan akan diberikan terkait dengan kesesuaian dengan kebutuhan dan potensi yang dimiliki oleh masyarakat yang dikenai oleh program CSR tersebut. Oleh sebab itu Tweelvetrees (1991) memandang pemetaan sosial sebagai salah satu pendekatan dalam pengembangan masyarakat yang merupakan bagian dari program CSR.

Pemetaan sosial (social mapping) didefinisikan sebagai proses penggambaran masyarakat yang sistematik serta melibatkan pengumpulan data dan informasi mengenai masyarakat termasuk di dalamnya profil dan masalah sosial yang ada pada masyarakat tersebut. Merujuk pada Netting, Kettner dan McMurtry (1993), pemetaan sosial dapat disebut juga sebagai social profiling atau "pembuatan profile suatu masyarakat".

Kecamatan Padalarang pada awalnya merupakan salah satu Kecamatan yang ada di Kabupaten Bandung, akan tetapi setelah ada pemekaran pada tahun 2006 maka wilayah Kecamatan Padalarang menjadi wilayah dari Kabupaten Bandung Barat (KBB) dan Kecamatan Padalarang pun dijadikan sebagai pusat kota dari KBB.

Melihat letak Kecamatan Padalarang yang dilalui oleh jalan raya dan berada di pusat kota KBB mendukung kegiatan ekonomi masyarakat. Kondisi ini didukung pula oleh sarana transportasi yang cukup memadai selain karena daerahnya yang mudah dijangkau dari berbagai arah. Secara tidak langsung, tersedianya sarana transportasi tersebut berpengaruh terhadap perkembangan kehidupan masyarakat dan dapat meningkatkan mobilitas kehidupan masyarakat secara umum di Kecamatan Padalarang. Masyarakat Kecamatan Padalarang dapat dengan mudah memperoleh pengaruh dari luar dan dapat meningkatkan aktivitas yang lebih kompleks dari masyarakatnya ke luar daerah.

Secara geografis, Kecamatan Padalarang merupakan daerah bukan pesisir yang memiliki lahan yang subur dan memiliki potensi banyaknya aliran sungai menyebabkan sebagian besar dari luas tanahnya digunakan untuk pertanian. Topografi wilayah 100 persen dari jumlah desa/kelurahan di Kecamatan Padalarang berupa wilayah dataran. Luas wilayah Kecamatan Padalarang seluas $51,40 \mathrm{~km}^{2}$ yang tersebar pada 10 desa yang memiliki kontur tanah yang relatif bervariasi.

Kajian ini akan memusatkan perhatian pada kondisi sosial dan ekonomi masyarakat yang ada di sekitar perusahaan. Adapun wilayah yang dijadikan kasus dalam penelitian ini adalah masyarakat di Desa Kertajaya Kecamatan Padalarang Kabupaten Bandung Barat.

\section{Metode Penelitian}

Penelitian ini bermaksud untuk mengkaji kondisi sosial dan ekonomi masyarakat yang ada di sekitar perusahaan di Desa Kertajaya Kecamatan Padalarang Kabupaten Bandung Barat. Untuk mendapatkan gambaran mengenai kondisi sosial dan ekonomi masyarakat tersebut, maka dalam 
penelitian ini digunakan metode deskriptif dan pendekatan kualitatif.

Pengumpulan data dalam kegiatan ini terdiri dari data sekunder dan data primer. Data sekunder diarahkan kepada dokumen-dokumen terkait dengan gambaran umum masyarakat di Kecamatan Padalarang Kabupaten Bandung Barat. Sedangkan data primer diarahkan untuk menggali informasi secara langsung di lapangan terkait dengan kondisi sosial dan ekonomi, yang dilakukan dengan cara menggunakan wawancara mendalam serta melakukan Focus Group Discussion. Penelitian ini melibatkan 30 orang informan yang dipandang memiliki pengetahuan dan informasi mengenai kondisi di desa-desa yang ada di Kecamatan Padalarang. Informan tersebut terdiri dari aparat pemerintahan desa, tokoh masyarakat, serta masyarakat awam yang ada di setiap desa.

\section{Kondisi Sosial Masyarakat di Desa Kertajaya}

Kondisi sosial masyarakat di Desa Kertajaya dapat diuraikan dalam empat kategori, yaitu: nilai dan norma masyarakat; kepercayaan antar masyarakat; kearifan lokal; serta potensi konflik.

\section{Nilai dan norma dalam masyarakat}

Norma dan nilai mempunyai kaitan yang sangat erat dalam rangka mempengaruhi perilaku masyarakat agar tercipta keteraturan dalam tatahubungan antar warga masyarakat. Norma sosial dibuat untuk melaksanakan nilai-nilai yang dianggap baik dan benar oleh masyarakat. Oleh sebab itu norma dilengkapi dengan sanksi-sanksi sebagai bentuk ikatan bagi semua masyarakat untuk mematuhinya. Dalam suatu masyarakat nilai dan norma terus mengalami perkembangan sesuai dengan peradaban masyarakat tersebut. Masyarakat Kecamatan Padalarang adalah salah satu masyarakat yang sampai hari ini masih memiliki norma dan nilai yang menjadi suatu kesepakatan bersama antar warganya. Masyarakat di wilayah desa Kertajaya masih sangat anti dengan kegiatan-kegiatan yang sifatnya melanggar anturan agama, sehingga kegiatan-kegiatan yang dibuat oleh masyarakat diterapkan aturan untuk tidak membuat kegiatan sampai tengah malam, hal ini dilakukan guna meminimalisir perilaku-perilaku yang kurang baik seperti mabuk-mabukan, judi, berkelahi dan hal-hal lain yang mengganggu ketertiban umum.
Perilaku gotong royong dan saling membantu antar warga juga masih dilakukan oleh masyarakat di Kecamatan Padalarang. Hal ini dilakukan untuk menjaga kepedulian sosial antar masyarakatnya. Perilaku seperti tersebut tercermin dari beberapa kegiatan, misalnya dalam proses pelaksanaan kegiatan pembangunan rumah tidak layak huni masyarakat akan saling membantu, baik tenaga secara langsung ataupun memberikan tambahan bantuan materi untuk proses pembangunan rumah tersebut. Selain itu, kegiatan gotong royong lain yang sering menarik banyak partisipasi masyarakat adalah pembangunan sarana fasilitas umum, diantaranya seperti pembangunan MCK, pembangunan rumah ibadah dan lain-lain.

\section{Kepercayaan antar masyarakat}

Kepercayaan antar masyarakat merupakan salah satu modal sosial yang harus dimiliki oleh sebuah kelompok, khususnya dalam hal ini adalah masyarakat Kecamatan Padalarang. Sikap saling percaya antar masyarakat ini akan dapat muncul ketika ada proses interaksi yang intens dari anggota masyarakatnya, sehingga antar masyarakat akan paham karakteristik dan perannya masing-masing dalam masyarakat. Begitu juga dengan masyarakat Padalarang, mereka membangun interaksi antar warganya pada saat kegiatan-kegiatan bersama seperti kerja bakti dan gotong royong.

Kegiatan-kegiatan tersebut menjadi sebuah wadah bagi masyarakat untuk dapat saling mengenal kepribadian dan keterampilan yang dimliki anggota masyarakat lainnya. Sehingga pada akhirnya masyarakat akan dapat saling mendukung, menghomati dan menghilangkan rasa curiga terhadap anggota warga lainnya. Dengan adanya sikap saling percaya inilah kemudian pembangunan yang dilakukan di Kecamatan Padalarang terus mendapat dukungan dari semua pihak, baik pemerintah, masyarakat bahkan swasta.

\section{Kearifan lokal}

Kearifan lokal merupakan produk budaya masa lalu yang secara terus-menerus dijadikan pegangan hidup oleh pengikutnya. Akan tetapi meskipun bernilai lokal nilai yang terkandung didalamnya dianggap sangat universal. Kearifan lokal ini diajarkan secara turun-temurun dan diwariskan dari generasi ke generasi secara lisan maupun tulisan. Warga masyarakat Padalarang sampai saat 
ini masih terus menjaga warisan kearifan lokal yang di wariskan oleh leluhurnya, misalnya saja dari segi penggunaan bahasa sehari-hari masyarakat sangat masih sangat kental dengan penggunaan bahasa leluhurnya bahasa sunda.

Nilai lokal lain yang masih dilestarikan adalah nilai gotong royong dan kebersamaan. Nilai gotong rotong ini dapat tercermin dari kegiatan-kegiatan pembangunan fasilitas umum seperti pembangunan jalan, MCK, rumah ibadah dan renovasi rumah warga miskin. Kemudian untuk nilai kebersamaannya masyarakat padalarang masih menjaga tradisi saling membantu antar warganya, penarikan dana sosial tidak jarang dilakukan oleh orang-orang yang ditunjuk kepala Desa untuk tujuan membantu warga yang sedang sakit atau terkena musibah. Dengan terus menjalankan kearifan lokal ini berarti masyarakat telah sadar bahwa gotong royong dan kebersamaan atau keguyuban merupakan hakikat kehidupan manusia yang saling membutuhkan satu sama lain. Mereka sangat menyadari bahwa keterbatasan hanya dapat diatasi dengan kebersamaan.

\section{Potensi konflik}

Masyarakat Padalarang adalah masyarakat yang cukup majemuk. Mereka memiliki keanekaragaman budaya, agama, kesukuan, kedaerahan, adat istiadat dan tradisi sosial yang dianut setiap warganya. Hal ini dipengaruhi oleh banyaknya pendatang yang bertempat tinggal disana, mereka datang dari berbagai daerah dengan maksud mencari peluang pekerjaan yang ada di wilayah Padalarang. Kondisi ini tidaklah aneh karena di wilayah Padalarang telah banyak dibangun industri-industri pabrik yang menyerap banyak tenaga kerja. Hal inilah yang menjadi salah satu faktor banyaknya pendatang dari luar daerah datang dan tinggal di Padalarang.

Banyaknya pendatang ini tentunya menjadi ancaman tersendiri bagi warga masyarakat lokal. Ancaman tersebut muncul dari ketersediaan lahan tempat tinggal, peluang lapangan kerja bagi masyarakat lokal yang akan banyak ambil oleh para pendatang. Kemudian potensi konflik lain muncul dari beragamnya budaya dan agama yang dianut oleh warga pendatang, sehingga dapat memicu gesekan antara agama dan budaya yang dipegang oleh warga lokal dan pendatang. Potensi konflik lain muncul dari keberadaan perusahaan dan pabrik yang kegiatan operasionalnya mengganggu kegiatan masyarakat setempat, khususnya untuk polusi udara dan bunyi yang ditimbulkan oleh mesin yang dioperasikan pabrik.

\section{Kondisi Ekonomi Masyarakat di Desa Kertajaya}

Kondisi ekonomi masyarakat di Desa Kertajaya Kecamatan Padalarang Kabupaten Bandung Barat dapat digambarkan dari identifikasi kelompok rentan yang terdapat di Desa Kertajaya Kecamatan Padalarang Kabupaten Bandung Barat.

Berdasarkan gambaran umum berbagai aspek Kecamatan Padalarang secara umum dan Desa Kertajaya dapat diidentifikasi mengenai kelompok rentan. Kelompok rentan adalah semua orang yang menghadapi hambatan atau keterbatasan dalam menikmati standar kehidupan yang layak bagi kemanusiaan dan berlaku umum bagi suatu masyarakat yang berperadaban. Di Desa Kertajaya jumlah keluarga pra sejahtera berjumlah 406 Kepala Keluarga atau berada di bawah empat desa lainnya di Kecamatan Padalarang. Jumlah 406 Kepala Keluarga yang tergolong sebagai keluarga pra sejahtera tersebut tersebar ke lima dusun di Desa Kertajaya. Diketahui juga di Desa Kertajaya terdapat sejumlah 3800 jiwa penerima Jamkesmas/Jamkesda.

Kelompok rentan selanjutnya adalah masyarakat di sekitar tempat pembuangan sampah Desa Kertajaya, tempat pembuangan sampah berada di Dusun 2 dimana dampak yang dirasakan mencakup sebagian masyarakat Dusun 1 dan Dusun 2. Kondisi tempat pembuangan sampah yang tidak teratur dan terawat dengan baik mengancam masyarakat di sekitar tempat pembuangan sampah. Masyarakat di sekitar tempat pembuangan sampah rentan akan gangguan kesehatan karena kondisi lingkungan yang kotor dan bau. Selain itu juga masyarakat juga rentan terkena polusi udara yang timbul akibat sampah yang tidak teratur dan menumpuk di tempat pembuangan sampah.

Kelompok rentan juga terdapat di Kampung Simpang atau RW 8 dan 6. Kondisi RW 8 dan RW 6 yang sebagian besar masyarakatnya pendatang atau sekitar $80 \%$ memberikan potensi konflik di Desa Kertajaya. Kondisi ini juga sama dengan di kampung RW-RW di Kebon Kelapa Desa Kertajaya, di mana kondisi sama dengan kondisi di RW 8 dan RW 6 banyak masyarakat pendatang yang disebabkan oleh banyak industri dan perusahaan di 
sekitar Desa Kertajaya. Banyaknya pendatang tersebut membuat kondisi Desa Kertajaya khususnya RW 8 dan RW 6 menjadi majemuk. Banyaknya pendatang tersebut tentunya menjadi ancaman tersendiri bagi warga masyarakat lokal. Kemudian potensi konflik lain muncul dari beragamnya budaya dan agama yang dianut oleh warga pendatang, sehingga dapat memicu gesekan antara agama dan budaya yang dipegang oleh warga lokal dan pendatang.

Kelompok rentan lainnya adalah masyarakat di sekitar perusahaan dan industri yang berada di lingkungan Desa Kertajaya. Keberadaan industri dan perusahaan memberikan banyak dampak kepada masyarakat di sekitarnya seperti dampak kesehatan yang diakibatkan oleh polusi perusahaan serta potensi konflik masyarakat dengan perusahaan. Kelompok rentan ini tersebar di berbagai dusun dengan perusahaan dan industri yang berbeda, seperti Dusun 2 dengan TBBM Pertamina, dusun 4 dengan Combiphar dan Indofood, Serta Dusun 5 dengan Perumahan Kota Baru.

\section{Penutup}

Kondisi sosial masyarakat di Desa Kertajaya Kecamatan Padalarang Kabupaten Bandung Barat dapat disimpulkan kedalam empat kategori, yaitu: 1) nilai dan norma dalam masyarakat, yang mana masyarakat Desa Kertajaya masih sangat menghormati nilai dan norma keagamaan. Selain itu juga masyarakat Desa Kertajaya masih menjaga nilai-nilai budaya sunda yang sudah lama melekat di masyakat Desa Kertajaya. Hal ini terlihat dari setiap kegiatan yang dilaksanakan oleh masyarakat bersifat membangun kepedulian (gotong royong) antar masyarakat serta menjauhi perilaku yang bersinggungan dengan nilai-nilai dan tata aturan yang ada di masyarakat seperti mabuk, judi, dan hal lain yang mengganggu ketertiban umum. 2) Kepercayaan antar masyarakat, yang mana kepercayaan antar masyarakat dapat terlihat dalam kegiatan bersama seperti gotong royong atau kerja bakti yang dapat membangun interaksi antar warga. 3) Kearifan Lokal, dalam hal ini masyarakat Desa Kertajaya masih terus menerus memegang teguh kebudayan sunda yang telah diwariskan secara turun temurun dari generasi ke generasi, secara lisan maupun tulisan. Hal ini terwujud dari bahasa sehari-hari masyarakat Desa Kertajaya yang masih kental dengan bahasa leluhurnya. Selain itu nilai lokal masih terus dilestarikan di masyarakat Desa Kertajaya seperti gotong royong yang tercermin dalam kegiatan pembangunan fasilitas umum. Masyarakat percaya kebersamaan merupakan hakikat kehidupan manusia yang selama hidupnya saling membutuhkan satu sama lain. 4) Potensi konflik, dalam hal ini masyarakat Desa Kertajaya adalah masyarakat yang cukup majemuk, baik dari sisi keanekaragaman budaya, agama, kesukuan, adat istiadat, dan tradisi sosial yang dianut oleh setiap warganya. Hal ini dipengaruhi oleh banyaknya pendatang yang bermukim di wilayah Desa Kertajaya. Banyaknya pendatang tentunya menjadi ancaman tersendiri bagi masyarakat lokal. Ancaman tersebut muncul dan dapat berpotensi konflik dari beragamnya budaya dan agama yang dianut oleh warga pendatang sehingga dapat memicu gesekan dalam masyarakat. Kemudian mengenai kondisi ekonomi Desa Kertajaya dijelaskan melalui dua aspek yaitu mata pencahariaan dan angka kemiskinan. Mata pencaharian Desa Kertajaya mengalami pergeseran, yang pada awalnya berprofesi sebagai petani bergeser menjadi buruh pabrik seiring dengan pembangunan industri di kawasan Desa Kertajaya. Begitu pula dengan angka kemiskinan Desa Kertajaya, tercatat sebanyak 406 Kepala Keluarga yang termasuk ke dalam keluarga pra sejahtera.

\section{Daftar Pustaka}

Adamson, D. 2010. Community empowerment: Identifying The Barriers to "purposesful" Citizen Participation. International Journal of Sociology vol. 30 3/4 , 114-126.

Adi, I. R. 2003. Empowerment, Community Development $<$ and Community Intervention. Jakarta: FE-Universitas Indonesia.

. 2003. Pemberdayaan, Pengembangan Masyarakat< dan Intervensi Komunitas. Jakarta: LP.FE- Universitas Indonesia.

.2007. Perencanaan partisipatoris berbasis aset komunitas: dari pemikiran menuju penerapan. Jakarta: FISIP UI Press.

Alfitri. 2010. Program Community Development Perusahaan Migas Dalam Penguatan Modal Sosial. Bandung :Pascasarjana UNPAD 


\begin{tabular}{|c|c|c|c|c|}
\hline $\begin{array}{c}\text { Jurnal Penelitian \& } \\
\text { PPM }\end{array}$ & ISSN: 2442-448X & Vol 4, No: 2 & Hal: $129-389$ & Juli 2017 \\
\hline
\end{tabular}

Amaeshi, K. and Adi, A. B. C. 2007. Reconstructing the Corporate Social Responsibility Construct in Utlish. Business Ethics: A European Review vol. 16, pp:3-18

Babbie, A. R. 2005. Research Methods for Social Work. Belmont: Thomson Brooks/Cole.

Bryman, A. 2005. Integrating Quantitative and Qualitative Research: Prospects and Limits. Economic and Social Research Council

Butcher, H., Banks, S., Henderson, P., Robertson, J. 2003. Managing The Community Practice : Principles, Policies, and programmes. Bristol : Policy Press

Cary, L.J. 1970. Community Development As a Process. Columbia: University of Missouri Press

Elkington, J. 1997. Cannibals with Forks: The Triple Bottom Line of 21st Century. Philadelphia: New Society.

Eweje, G. 2007. Multinational oil companies' CSR Initiatives in Nigeria. Managerial Law Vol.49, 218-235.

Fatah, L. 2008. The Impacts of Coal Mining on the Economy and Environment of South KAlimantan Province, Indonesia. Asean Economic Bulletin vol 25 , 85-98.

Frank den Hond, F.G. 2007. Managing CSR in Action; Talking, Doing, and Measuring. England: Ashgate Publishing Limited.

Frynas, J. G. 2009. Beyond orporate Soial Responsibility. New York: Cambridge University Press.

Garriga, Elisabet ., D. M. 2004. Corporate Social Responsibility Theories: Maping the
Territory. Journal of Business Ethics vol 53 , 51-71.

Griffin, A. 2008. Reputation Management "Gaining Control of Issues, Crises and CSR. London: Kogan Page.

Herbert J. Rubin, I. S. 1992. Community Organizing and Development 2nd Edition. New York: Macmillan Publishing Company.

Hirshland, M. J. 2006. Corporate SSocial responsibility and The Shaping of G. New York: Palgrave Macmillan.

Hopkins, M. 2007. Corporate Social Responsibility \& International Development; Is Business The Solution?. United Kingdom: Earthscan.

Ife, J. 2000. Community Development: Community-Based Alternatives in Age of Globalization. Melbourne: Longman.

Ife, Jim., F. T. 2007. Community Development : Communit-based alternatives in age of globalization. Melbourne: Longman.

Kapelus, P. 2002. Mining, Corporate Social Responsibility and the "Community" : The Case of Rio Tinto, Richard Bay Minerals and the Mbonambi. Journal of Business Ethics , 275-296.

Raharjo, ST. 2015. Assessment untuk Praktik Pekerjaan Sosial dan Kesejahteraan Sosial. Bandung: Unpad Press 2015. Dasar Pengetahuan Pekerjaan Sosial. Bandung: Unpad Press.

2015. Keterampilan Pekerjaan Sosial: Dasar-dasar. Bandung, Unpad Press. 